DIGITALCOMMONS

— @WAYNESTATE —
Michigan Journal of Counseling:

Research, Theory and Practice

3-1-2014

\title{
The Relationship between Racial Identity and Acculturative Stress among African American Students in Counselor Training Programs
}

\author{
Tiffany A. Stewart \\ Midwestern State University \\ Delila Owens \\ University of Akron \\ John E. Queener \\ University of Akron \\ Cynthia A. Reynolds \\ University of Akron
}

Follow this and additional works at: https://digitalcommons.wayne.edu/mijoc

\section{Recommended Citation}

Stewart, T. A., Owens, D., Queener, J. E., \& Reynolds, C. A. (2014). The Relationship between Racial Identity and Acculturative Stress among African American Students in Counselor Training Programs, Michigan Journal of Counseling, 41(1), 4-17. doi:10.22237/ mijoc/1393632060 
The Relationship between Racial Identity and Acculturative Stress
among African American Students in Counselor Training Programs

Tiffany A. Stewart

Midwestern State University

Delila Owens, John E. Queener, and Cynthia A. Reynolds

University of Akron

In this study, we examined racial identity and acculturative stress among 116 African American counselor education graduate students in Council for the Accreditation of Counseling and Related Educational Programs (CACREP) accredited programs. Results indicated that racial identity and acculturative stress remain viable variables to take into account with African American students in counselor education programs. The participants in this study showed significant acculturative stress in their graduate programs. Implications for counselor education training programs are discussed.

The Relationship between Racial Identity and Acculturative Stress among African American Students in Counselor Training Programs

Given the consistently increasing number of diverse racial/ethnic individuals within the United States population, counselor trainees are more and more likely to be faced with individuals in need of their expertise (Sue \& Sue, 2008; Richeson \& Nussbaum, 2004). We tend to seek out, respond to things that are familiar and similar to ourselves (Baron \& Bryne, 2000). People of color tend to favor therapists who are both culturally sensitive and understand their worldview (Coleman et al., 1995; Nagayama Hall \& Maramba, 2001). Hence, training a more diverse group of therapists is critical. Sue (1993) and Smith (1985) emphasized that continued underrepresentation of minority groups in professional counselor training programs feeds into established perceptions that mental health services are only for middle-class White Americans and illequipped to meet their needs. To the extent that universities are successful in

Dr. Stewart is an assistant professor at Midwestern State University. She has been involved in counseling for over 12 years, in the areas of rehabilitation, mental health, school, and college.

Delila Owens is an associate professor of School Counseling and Counselor Education. Her primary research interests include school counseling, multicultural counseling and urban education.

John Queener is a Professor at The University of Akron. His research interests surround culturally specific interventions and resistance to Multiculturalism.

Cynthia A. Reynolds is a Professor at The University of Akron. Her research interests include Filial therapy, gestalt therapy and school counseling. 
training and graduating counselors from an array of racial and ethnic backgrounds, this could aid in reducing the reluctance of people of color to seek counseling services. More specifically, the visibility of a diverse group of counselors may reduce the stigma of mental health services and aid in reducing cultural mistrust (Corrigan, 2004).

The highest concentration of African American doctoral students (93 students total 25 males and 68 females) reside in the Southern region of the United States (Johnson, Bradley, Knight, \& Bradshaw, 2007). At the time of their study, a total of 825 students were currently enrolled in Council for the accredited counseling and related educational programs. One hundred forty-eight (17.9\%) were African American; 44 (5.3\%) of which were men and 104 (12.6\%) were women. In this study we examined a mediator of acculturative stress among African American students in CACREP-accredited programs counselor education training programs.

The primary purpose of our study was to examine the relationship between racial identity and acculturative stress among African American graduate students in counselor education training programs. Based on the results of prior research (Thompson, Anderson \& Bakerman, 2000), we hypothesized that there would be a positive relationship between racial identity and acculturative stress.

Racial identity has been shown to influence one's self-esteem, quality of life, emotional well-being, and feelings toward education (Cokley, 2007; Sue \& Sue, 2008). Furthermore, prior studies have suggested that race-related stress, commonly referred to acculturative stress, does impact racial identity, sense of self, and the management of stress (Cokley, 2005; Inman, 2006; Pierre \& Mahalik, 2005; Rhee, Chang, \& Rhee, 2003; Takeuchit et al., 2007). Scholars have discovered a consistent correlation between racial identity and acculturative stress among various races and ethnicities. (Aponte \& Wohl, 2000; Carter \& Reynolds, 2011; Inman, 2006; Inman, \& Ettigi, 2011; Mejia \& McCarthy, 2010; Thompson, Anderson \& Bakerman, 2000; Torres, Driscoll, \& Voell, 2012; Tummala-Narra, Alegria, \& Chen, 2012). However, researchers have given little attention to exploring the relationship between these two paradigms among African American graduate students in CACREP accredited counseling programs. Council for Accreditation of Counseling and Related Educational Programs (CACREP) is considered the hallmark of training standards for counselor education programs in the United States. Examining their affects within this population could inform and contribute to the design of a renewed programmatic approach capable of bolstering student recruitment and, more importantly, retention. The level of importance that African Americans place on their racial/cultural group can have profound implications in terms of their coping strategies and general emotional well-being (Bettencourt, Charlton, Eubanks, Kernahan, \& Fuller, 1999).

\section{Racial Identity}

Racial identity is conceptualized as several contextual attitudes that govern how well or the manner in which individuals identify with their respective racial groups (Cokely, 2007; Cross \& Vandiver, 2001). Identity formation plays a key role in psychological development, future achievement, and even physical health (Brondolo, Brady ver Halen, Pencille, Beatty, \& Contrada, 2009; Chav- 
ous et al., 2003; Kroger, 2007). Leading developmental models of racial and ethnic identity (Cross, 1971, 1991, 1995; Helms, 1995; Phinney, 1990) also have associated identity formation with healthy growth. In the 1960s, African American psychologists began to expand and redefine the term racial identity to include consideration of oppression and culture experiences in the lives of African Americans (Gaines \& Reed, 1994, 1995).

Cross (1991) conceptualized Black identity development as consisting of three specific stages: (a) pre-encounter, (b) immersion-emersion, and (c) internalization. The pre-encounter stage entails having either pro-White or antiBlack attitudes, which are labeled as pre-encounter assimilation identity (proAmerican with low-race salience) and pre-encounter anti-Black identity. The latter entails two dimensions: Miseducation (stereotypical views about Blacks) and self-hatred (negative views towards one's own Blackness). Next, the immersion-emersion stage identifies the point of transition between the old and emergent identities following an encounter with significant events (e.g. experiencing racism or discrimination personally) that inspire curiosity about racial identity. Exposure to these events may lead individuals to rebel against the dominant culture and instead seek out acceptance by immersing themselves within their own Black culture. Finally, the internalization stage encompasses behaviors, attitudes, and metal health propensities that accompany habituation to the new identity. African Americans in this stage are comfortable within their culture but are equally willing to embrace other cultures, worldviews, and differences (Vandiver, Fhagen-Smith, Cokley, Cross, \& Worrell, 2001).

\section{Acculturative Stress}

There is a considerable amount of evidence that suggests unfavorable race-related experiences provoke strong emotional reactions which include, but are not limited to, anger, anxiety, poor sense of self, and depression (Sue \& Sue, 2012; Swim, Hyers, Cohen, Fitzgerald, \& Bylsma, 2003; Yip, Seaton, \& Sellers, 2006). Dressler and Bernal (1982) define acculturated stress as individuals not having the proper adaptive resources to properly adjust to a new cultural setting. The extent to which African American students are able to form a positive or negative racial identity is a significant predictor of reported levels of acculturative stress. Thus, for the purpose of this study, acculturative stress is defined as a measure of psychological discomfort experienced in dealing with Whites, which may be affected by the effective usage of coping strategies in the face of everyday social pressures (Thompson, Anderson, \& Bakeman, 2000). The experiences of African American students negotiating challenges at predominately white institutions have been the subject matter of earlier studies (Bourne, 2001; Ferguson, 2003). Most commonly, this research has been in relation to racism, contact with faculty, and monocultural curriculums. However, few studies to date, have explored the relationship between acculturative stress and racial identity in African American students in this environment.

\section{Method}

\section{Data Collection and Procedures}

Approval by the Institutional Review Board (IRB) of the lead re- 
searcher's institution was obtained to conduct this study and collect data. An online survey was used for the purpose of collecting data for this study. Names of department chairs and professors in Counselor Graduate Education programs were obtained from the CACREP Directory of Accredited Programs. Contact was made via email and phone to department chairs and professors and asked to distribute surveys via listservs as a resource to reach participants in a broad fashion. In addition, graduate schools and offices of graduate services affiliated with universities that offer Counselor Education graduate programs were also contacted via email and phone and asked to distribute the surveys via listservs to their African American graduate students. Approximately 200 graduate programs were contacted. Furthermore, the CESNET listserv was utilized to solicit participants.

\section{Participants}

Participants were 116 African American masters' and doctoral level students attending CACREP-accredited Counselor Education programs across the United States. Participants ranged in age from 22-59 years old. Average age of participants was 31 years. There were 99 women and 17 men. Just over $60 \%$ of the participants were pursuing a masters' degree, while $38.9 \%$ were working towards a Ph.D. The largest percent, about 39\%, of the participants were specializing in Mental Health and Community Counseling. This was followed by Counselor Education and Supervision (27.7\%), School (21.4\%) and Marriage and Family $(11.6 \%)$. Just over $67 \%$ of the participants were in their first or second year in their training program institutions. Over $81 \%$ of the participants reported attending predominantly white schools.

\section{Research Design}

Two measurement instruments and a demographic questionnaire were utilized to obtain psychometric data and test hypotheses: the CRIS (Vandiver et al., 2000), the Acculturative Stress Scale (ACS; Williams-Flournoy \& Anderson, 1996), and a demographic questionnaire (e.g., age, sex, race, undergraduate experience, and graduate level). For this study, a power analysis, utilizing an alpha of .05 , a medium effect size of .15 (Cohen, 1992) with a power set to .80 , revealed that 85 participants were needed.

\section{Measures}

Demographic questionnaire. Items on background information included sex, age, degree pursuing, year in program, specialization area, undergraduate experience, and overall satisfaction. The questionnaire was composed by the lead researcher. The demographic questionnaire was developed to collect information on our sample population.

Racial identity. The Cross Racial Identity Scale (CRIS; Vandiver et al., 2000 ) is an instrument that measures racial attitudes determined by the Expanded Nigrescence theory (Cross \& Vandiver, 2001). The items identify several different identity doctrines of African Americans. The CRIS consists 40 items, which includes six types of racial attitudes: pre-encounter assimilation (PA), pre- 
encounter miseducation (PM), pre-encounter self-hatred (PSH), immersion/ emersion anti-White (IEAW), internalization afrocentricity (IA), and internalization multiculturalist-inclusive (IMCI), each measured by five items that are randomly distributed (30 CRIS items and 10 fillers).

Pre-encounter assimilation (PA) measures how one identifies as an American first and secondly in relation to race (Cross \& Vandiver, 2001; Vandiver, Cross, Worrell, \& Fhaqen-Smith, 2002). A sample item is "I am not so much a member of a racial group, as I am an American". Pre-encounter miseducation (PM) focuses on stereotypical views negatively associated with African Americans (e.g.,"Blacks place more emphasis on having a good time than on hard work"). The essence of the pre-encounter self-hatred (PSH) items is on the internalization of negative perceptions of being Black (e.g. "Privately, I sometimes have negative feelings about being Black"). Immersion-emersion antiwhite (IEAW) items measure the degree of contempt for White Americans (e.g., I hate white people). Internalization afrocentricity (IA) items accent a strict focus from a Blackness or "afrocentric" frame of reference (e.g. Black people will never be free until we embrace an afrocentric perspective). In contrast, internalization multiculturalist inclusive (IMCI) items identity persons who incorporate a balance of diversity that is all encompassing of all cultures (e.g., "I am connected to many groups (Hispanics, Asian Americans, White Euro-Americans, Jews, gay men and lesbians, etc.") The CRIS is items are rated on a 7-point Likerttype scale (that ranges from $1=$ strongly disagree to $7=$ strongly agree) selfreport inventory. Items on each subscale are totaled to reflect the endorsement of each attitude. Scores range from 5-35, with the higher number corresponding to a particular attitude. The CRIS provides no global score (Cross \& Vandiver, 2001; Worrell, Cross, \&Vandiver, 2001).

Cronbach's alpha coefficients of the CRIS are the following for the six subscales: Pre-encounter assimilation $=.85$, Pre-encounter miseducation $=.78$, Pre-encounter anti-Black $=.89$, immersion-emersion anti-White $=.89$, internalization Black nationalist $=.83$, and internalization multiculturalist $=.82$. There was high internal reliability of the sub instruments used in this study. Confirmatory and exploratory factor analyses yielded reinforcement for the six-factor solution (Vandiver et al., 2002; Worrell \& Watson, 2008). Convergent validity for the CRIS was determined with the Multidimensional Inventory of Black Identity (Simons, Worrell, \& Berry, 2008; Vandiver et al., 2000) and the African Self Conscious Scale (Simmons et al., 2008). In addition, strong evidence of discriminant validity was reported correlating subscale scores and the Big Five personality traits, global self-esteem, and social desirability scores (Vandiver et al.; Worrell et al., 2000). The CRIS does not yield a total composite score.

Acculturative Stress. Acculturative Stress Scale (ACS; WilliamsFlournoy \& Anderson, 1996) includes 9-items that consists of the subscales Ethnocentrism, Received Racism, and Perceived Racism. It is rated on a 5point Likert-type scale (ranges from strongly agree to strongly disagree) and was designed to assess the degree of psychological discomfort experienced by African Americans assimilating into an unfamiliar cultural environment. A sample item is "I get especially nervous going into a room full of people if I am going to be the only one of my ethnic group". Cronbach's alpha coefficients of the 
ACS are the following for the nine items: item $=.73$, item $2=.56$, item $3=.42$, item $4=.77$, item $5=.72$, item $6=.81$, item $7=.73$, item $8=.70$, and item 9 $=.73$. All items except for item 2 have a standard deviation of at least 2.3. A series of item analysis was performed in order to assess the relative contribution of each item to the scale. There is evidence of concurrent validity for the ACS based in its correlation with Spielberger's Trait Anxiety Scale (Spielberger, 1972) and Rosenberg's Self-Esteem Scale (Rosenberg, 1965).

\section{Results}

The research findings supported the stated hypothesis: There was a significant relationship between Black racial identity and acculturative stress. This hypothesis was tested by investigating a correlation between the Acculturative Stress Scale Total and all of the Subscales from the CRIS (Table 1). A Pearson-Product Correlation was conducted to investigate these correlations. 


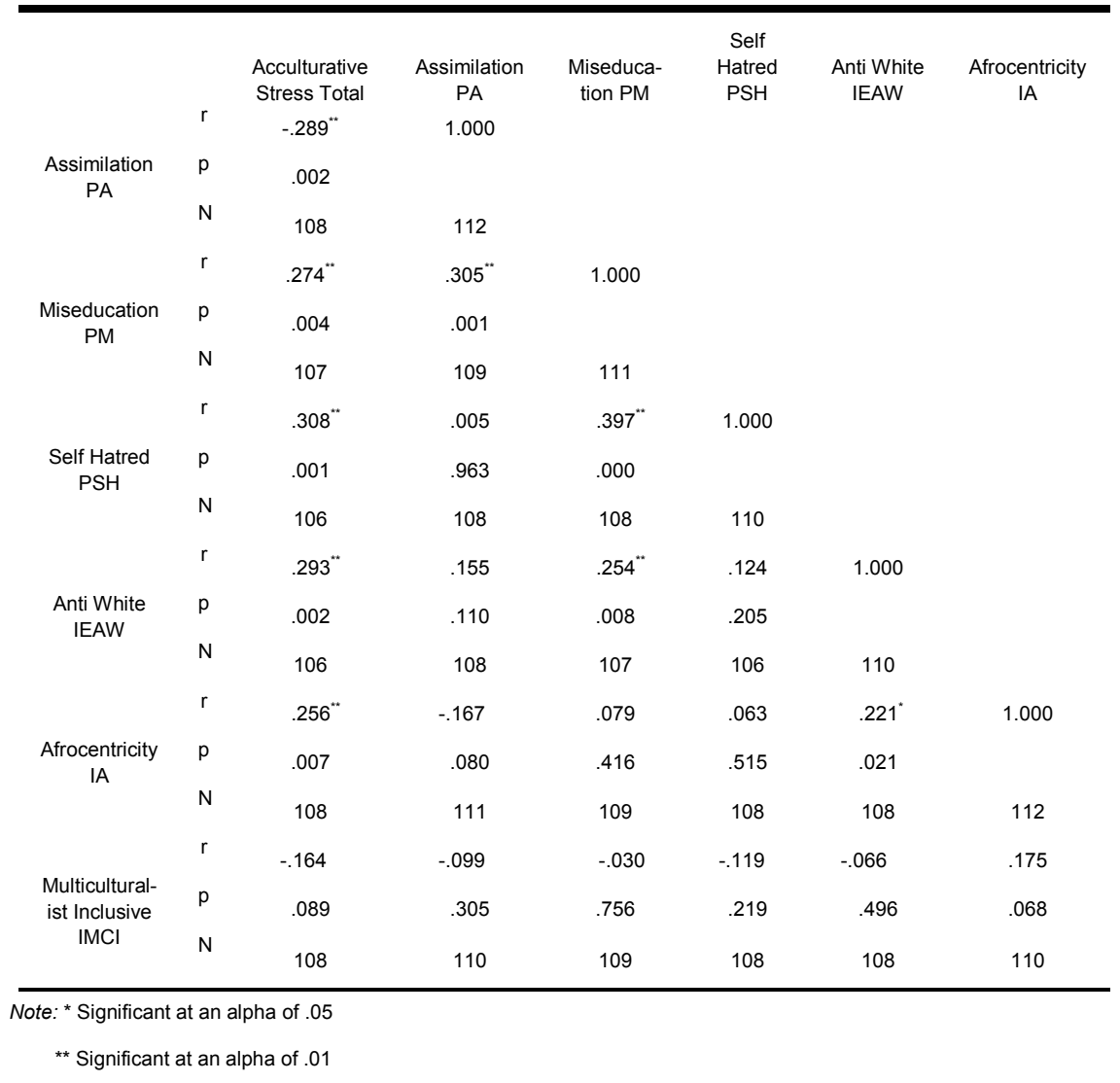

Specifically, the results were a statistically-significant negative relationship between assimilation (PA) attitudes and acculturative stress (-.289); a statistically-significant correlation between miseducation (PM) attitudes from the Cross Racial Identity scale and the Acculturative Stress scale (.274); a positive significant correlation between pre-encounter self-hatred (PSH) attitudes and acculturative stress (.308); a statistically-significant positive relationship between anti-white (IEAW) attitudes and acculturative stress (.293); a positive significant relationship between afrocentricity (IA) attitudes and acculturative stress (.256); the relationship between multiculturalist (IMCI) attitudes and acculturative stress (-.164) was not statistically significant.

Our findings are consistent with prior literature, which indicates that there is a significant relationship between racial identity and acculturative stress among African Americans. An individual's racial identity could either contribute to acculturative stress (if they are less culturally aware) or help buffer the effects of acculturative stress (if they have a greater cultural awareness). In our results we found a negative correlation between Assimilation (PA) attitude scores and acculturative stress. Participants with greater cultural awareness 
were found to have less acculturative stress than participants who had lower cultural awareness. These findings are in line with Cross's (1971), Cross and Vandiver (2001), and Worrell, Cross, and Vandiver (2001) models of racial identity development in that attitudes characterized by pre-encounter logically appear to be the least healthiest because they involve negative stereotypes of one's own racial group and the potential for self-alienation. These results were in contrast to the literature in which Parham and Helms (1985) found that preencounter attitudes were related to a lower level of self-actualization, feelings of inferiority, hypersensitivity, anxiety, and lack of self-acceptance. Similarly, other researchers have found that pre-encounter attitudes were significantly related to higher levels of depression, negatively related to general well-being and selfesteem, and negatively related to self-concept (Wilcots, 2001; Wilson \& Constantine, 1999).

Research on Black racial identity and acculturative stress has indicated that one's racial identity could either contribute to acculturative stress (if they were less culturally aware) or help buffer the effects of acculturative stress (if they have a greater cultural awareness) (Thompson et al., 2000). The positive correlation between afrocentricity (IA) attitudes and acculturative stress was consistent with Thompson et al. (2000), which found that internalization attitudes and acculturative stress have a positive relationship. Thus, cultural awareness brings with it an experience of less acculturative stress.

The positive relationship between anti-white (IEAW) attitudes and acculturative stress means that a person with an anti-white attitude may have greater difficulty associating with the dominant culture and will possibly experience more acculturative stress than someone who does not identify with anti-white attitudes. These results were consistent with Neville, Heppner, and Wang (1997), which found that high immersion scores were related to greater levels of perceived general and cultural-specific stress, whereas high internalization scores were associated with lowered levels of perceived culture-specific stressors. However, there was inconsistency between the current study and the literature that found a positive relationship between pre-encounter self-hatred (PSH) attitudes and acculturative stress. Researchers found that acculturative stress scores were not related to racial identity in terms of multiculturalist inclusive (IMCl) attitudes.

\section{Implications}

Our focus in this current study was on the exploration of racial identity and reported levels of acculturated stress in African American counselor education students. Our findings supported previous research on the correlation between the two constructs dating back to the 1980s, which have consistently demonstrated that the interaction between students and their college environment is an important predictor of college-related behaviors (Allen, 1985; Fleming, 1984; Kimbrough, Sherry, \& Walton, 1996; Sedlacek, 1999). The findings from our study speak to the need to further examine variables that contribute acculturative stress in African American college students at all levels. It is possible that African American students' cultural interactions are vulnerable to misperceptions due to past experiences of discrimination and oppression (Obasi \& Leong, 2009). However, cultural awareness and sensitivity by program officials is crucial. Increasing African American students sense of belonging at all levels 
of education can aid in retention.

Developing a balanced perspective between both the individual and program could alleviate feelings of isolation and lower acculturative stress levels. By doing so, this would take the pressure off of students feeling the need to fit in, as well as not attaching the locus of the problem as residing solely in the individual (Cosgrove, 2006). Having supportive services available, such as mentoring programs, could assist African American graduate students to better adjust within their programs. In addition, providing peer advising, much like those offered in many undergraduate programs, could aid in a student's transition to graduate school and offer them a sense of belonging, security, and safety. Also, it may be helpful to incorporate interventions that focus on helping students of color be successful within their programs.

D'Andrea and Daniels (2001) asserted that the overt gap between counselor trainees who are neither White nor men, the steady increase of clients from diverse backgrounds, and the predominance of White, middle-class male counselor-educators and administrators could increase the chances that ethical and moral dilemmas may arise. African American students will maintain feelings of cultural mistrust towards academic institutions, thereby lowering their expectations of educational success and demonstrate lack of effort (Irving \& Hudley, 2005), possibly contributing to stereotype threat (feeling inferior and as a result acting as such). The resulting underrepresentation of African Americans in attendance and completion of counselor training programs then leads to a lack of multicultural presence in the profession.

If it is the goal of CACREP-accredited Counselor Education programs to recruit, retain, and graduate a diverse group of students, then programmatic changes must be implemented that move beyond minimum diversity requirements. The acknowledgment of these multicultural issues will allow counselor trainees to be better equipped to work with clients from diverse backgrounds. The results of this study also provided further support for the significance of racial identity (Elion, Wang, Slaney, \& French, 2012; Fuller-Rowell, Burrow, \& Ong, 2011) and acculturative stress in the lives of African American students (Carter \& Reynolds, 2011; Thompson et al., 2000). In particular, acculturative stress may be greater for African Americans who are less aware of their culture. It is fundamentally important for African American students to know how to effectively maintain a sense of self, while in a seemingly uncomfortable environment. Also, many supportive services or interventions, such as those mentioned above, may be ineffective, lacking, or simply nonexistent until they are introduced by the very students who they are meant to help. Taking a proactive role in reshaping the environment of the programs in which they are enrolled may prove to be beneficial for African American students.

Future studies might employ a mixed-method approach. Interviews could give further insight into an individual's perception and experiences that could assist in identifying sources and effects of environmental support on African American graduate students in CACREP-accredited counseling programs. Qualitative findings could further aid in understanding, thus developing specific areas within programs related to racial climate. This information could assist in the development of interventions specifically designed to address programmatic deficiencies, whereby validating student experiences and possibly facilitating successful retention and graduation rates. 


\section{Limitations}

Several potential limitations should be considered in light of the finding in this study. First, generalizability of the results is qualified because of the relatively small sample size, because only sixty-one point one percent were masters' level students and only $38.9 \%$ were doctoral students, the findings may not yield an accurate depiction of the experiences of doctoral students in counselor education programs. Future investigators should replicate this study with a considerably larger sample and equal representation students in both masters and doctoral programs. Inconsistencies regarding African American student's ratings of racial identity may have influenced the outcome of the results. Students with lower levels of racial identity may be in tune to the daily racial microaggressions and thus report lower rates on the racial identity instrument.

\section{References}

Allen, W. R. (1985). Black student, White campus: Structural, interpersonal, and psychological correlates of success. Journal of Negro Education, 54, 134-147.

Aponte, J. F., \& Wohl, J. (Eds.). (2000). Psychological intervention and cultural diversity. Boston, MA: Allyn and Bacon.

Baron, R. A. \& Byrne, D. (2000). Social psychology (9th ed.). Needham Heights, MA: Allyn and Bacon.

Bettencourt, B. A., \& Charlton, K., Eubanks, J., Kernahan, C., \& Fuller, B. (1999). Development of collective self-esteem among students: Predicting adjustment to college. Basic and Applied Social Psychology, 27, 213 -222. doi: 10.1207/S15324834BASP2103_5

Bourne, J. (2001). The life and times of institutional racism. Race \& Class, 43, 7 $-22$.

Brondolo, E., Brady ver Halen, N., Pencille, M., Beatty, D., \& Contrada, R. J. (2009). Coping with racism: A selective review of the literature and a theoretical and methodological critique. Journal of Behavioral Medicine, 32, 64-88. doi:10.1007/s10865-008-91930-0

Carter, R. T., \& Reynolds, A. L. (2011). Race-related stress, racial identity status attitudes, and emotional reactions of Black Americans. Cultural Diversity and Ethnic Minority Psychology, 17, 156-162. doi: 10.1037/ a0023358

Chavous, T. M., Bernat, D. H., Schmeelk-Cone, K., Caldwell, C. H., KohnWood, L., \& Zimmerman, M. A. (2003). Racial identity and academic attainment among African American adolescents. Child Development, 74, 1076-1090. doi: 10.1111/1467-8624.00593

Cohen, J. (1992). Statistical Power Analysis. Current Directions In Psychological Science, 1, 98-101. doi:10.1111/1467-8721.ep10768783.

Cokley, K. O. (2005) Racial(ized) identity, ethnic identity, and Afrocentric values: Conceptual and methodological challenges in understanding African American identity. The Journal of Counseling Psychology, 51, 517-526. doi: 10.1037/0022-0167.52.4.517

Cokley, K. O. (2007). Critical issues in the measurement of ethnic and racial identity: A referendum on the state of the field. Journal of Counseling Psychology, 54, 224-234. doi: 10.1037/0022-0167.54.3.224 
Coleman, H. L. K., Wampold, B. E., \& Casali, S. L. (1995). Ethnic minorities' rating of ethnically similar and European American counselors: A metaanalysis. Journal of Counseling Psychology, 42, 55-64.

Corrigan, P. (2004). How stigma interferes with mental health care. American Psychologist, 59, 614-625.

Cross, W. E., Jr. (1971). The negro-to-black conversion experience. Black World, 20, 3-27.

Cross, W. E., Jr. (1991). Shades of black: Diversity in African American identity. Philadelphia, PA: Temple University Press.

Cross, W. E., Jr. (1995). The psychology of nigrescence: Revising the Cross model. In J. G. Ponterotto, J. M. Casas, L. A. Suzuki, \& C. M. Alexander (Eds.), Handbook of Multicultural Counseling, 93-122. Thousand Oaks, CA: Sage.

Cross, W.E., Jr., \& Vandiver, B. J. (2001). Nigrescence theory and measurement: Introducing the Cross Racial Identity Scale (CRIS). In J. G. Ponterotto, J. M. Casas, L. M. Suzuki, \& C. M. Alexander (Eds.), Handbook of multicultural counseling, 2nd ed., 371-393. Thousand Oaks, CA: Sage.

D'Andrea, M., \& Daniels, J. (2001). Exploring the different levels of multicultural counseling training in counselor education. Journal of Counseling \& Development, 70, 78-85.

Dressler, W., \& Bernal, H. (1982). Acculturation and stress in low income Puerto Rican community. Journal of Human Stress, 8, 32-38.

Elion, A. A., Wang, K. T., Slaney, R. B., \& French, B. H. (2012). Perfectionism in African American students: Relationship to racial identity, GPA, selfesteem, and depression. Cultural Diversity and Ethnic Minority Psychology, 18, 118-127. doi: 10.1037/a0026491

Ferguson, R. F. (2003). Teachers' perceptions and expectations and the blackwhite test score gap. Urban Education, 38, 460-507.

Fleming, J. (1984). Blacks in college: A comparative study of students' success in Black and White institutions. San Francisco, CA: Jossey-Bass.

Fuller-Rowell, T. E., Burrow, A. L., \& Ong, A. D. (2011). Changes in racial identity among African American college students following the election of Barack Obama. Developmental Psychology, 47, 1608-1618. doi: 10.1037/a0025284

Gaines, S. O., \& Reed, E. S. (1994). Two social psychologies of prejudice: Gordon W. Allport, W. E. B. Du Bois, and the legacy of Booker T. Washington. Journal of Black Psychology, 20, 8-28.

Gaines, S. O., \& Reed, E. (1995). Prejudice: From Allport to Du Bois. American Psychologist, 50, 96-103.

Helms, J. E. (1995). An update on Helm's White and people of color racial identity model. In J. G. Ponterotto, J. M. Casas, L. M. Casas, L. A. Suzuki, \& C. M. Alexander (Eds.), Handbook of Multicultural Counseling, 181-198. Thousand Oaks, CA: Sage.

Inman, A. G. (2006). South Asian women: Identities and conflicts. Cultural Diversity and Ethnic Minority Psychology, 12, 306-319.

Irving, M., \& Hudley, C. (2005). Cultural mistrust, academic outcome expectations and outcome value among African American males. Urban Education, 40, 476-496. doi:10.1177/0042085905278019

Johnson, P., Bradley, C., Bradshaw, L., \& Knight, D. (2007). Preparing African 
Americancounselor education doctoral students for the professorate. College Student Journal, 41, 886-890.

Kimbrough, R. M., Molock, S. D., \& Walton, K. (1996). Perception of social support, acculturation, depression, and suicidal ideation among African. Journal Of Negro Education, 65, 295-307.

Kroger, J. (2007). Identity development: Adolescence through adulthood. Thousand Oaks, CA: Sage.

Mejia, O. L., \& McCarthy, C. J. (2010). Acculturative stress, depression, and anxiety in migrant farmwork college students of Mexican heritage. International Journal of Stress Management, 17, 1-20. doi: 10.1037/ a0018119

Nagayama Hall, G. C., \& Maramba, G. G. (2001). In search of cultural diversity: Recent literature in cross-cultural and ethnic minority psychology. Cultural Diversity \& Ethnic Minority Psychology, 7, 12-26.

Neville, H. A., Heppner, P. P., \& Wang, L. (1997). Relations among racial identity attitudes, perceived stressors, and coping styles in African American college students. Journal of Counseling \& Development, 75, 303-311. doi: 10.1002/j.1556-6676

Obasi, E. M. \& Leong, F. T. L. (2009). Psychological distress, acculturation, and mental health seeking attitudes among people of African descent in the United States: A preliminaryinvestigation. Journal of Counseling Psychology, 56, 227-238. doi:10.1037/a0014865

Parham, T. A., \& Helms, J. E. (1985). Attitudes of racial identity and self-esteem of Black students: An exploratory investigation. Journal of College Student Personnel, 27, 143-147.

Phinney, J. S. (1990). Ethnic identity in adolescents and adults: Review of research. Psychological Bulletin, 108, 499-514. doi:10.1037/00332909.108.3.499

Pierre, M. R., \& Mahalik, J. R. (2005). Examining African self-consciousness and Black racial identity as predictors of Black men's psychological wellbeing. Cultural Diversity and Ethnic Minority Psychology, 11, 28-40.

Rhee, S., Chang, J., \& Rhee, J. (2003). Acculturation, communication patterns, and self-esteem among Asian and Caucasian American adolescents. Adolescence, 38, 154, 749-768.

Richeson, J. A., \& Nussbaum, R. J. (2004). The impact of multiculturalism versus color-blindness on racial bias. Journal of Experimental Social Psychology, 40, 417-423.

Rosenberg, M. (1965). Society and the adolescent self-image. Princeton, NJ: Princeton University Press.

Sedlacek, W. E. (1999). Black students on White campuses: 20 years of research. Journal of College Student Development, 40, 538-550.

Simmons, C., Worrell, F. C., \& Berry, J. M. (2008). Psychometric properties of scores on three Black racial identity scales. Assessment, 15, 259-276. doi: $10.1177 / 1073191108314788$

Spielberger, C. D. (1972). The nature and measurement of anxiety. In C. D. Spielberger (Ed.),Anxiety: Current trends in theory and research. New York, NY: Academic Press.

Smith, E. M. J. (1985). Ethnic minorities: Life stress, social support, and mental health issues. The Counseling Psychologist, 13, 537-579. doi: 
Sue, D. (1993). Confronting ourselves: The White and racial/ethnic-minority researcher. Counseling Psychologist, 21, 244-249.

Sue, D. W., \& Sue, D. (2008). Counseling the culturally diverse: Theory and practice. (5th ed.) New York, NY: John Wiley \& Sons.

Sue, D. W., \& Sue, D. (2012). Counseling the culturally diverse: Theory and practice (6th ed.). Hoboken, NJ: John Wiley \& Sons.

Swim, J. K., Hyers, L. L., Cohen, L. L., Fitzgerald, D. C., \& Bylsma, W. H.

(2003). African American college students' experiences with everyday racism: Characteristics of and responses to these incidents. Journal of Black Psychology, 29, 38-67. doi:10.1177/0095798402239228

Takeuchi, D. T., Zane, N., Hong, S., Chae, D. H., Gong, F., Gee, G. C., Alegria, M. (2007). Immigration-related factors and mental disorders among Asian Americans. American Journal of Public Health, 97, 84-90.

Thompson, P. C., Anderson, L. P., \& Bakeman, R. A. (2000). Effects of racial socialization and racial identity on acculturative stress in African American college students. Cultural Diversity and Ethnic Minority Psychology, 6, 196- 210. doi: 10.1037//1099-10.1037//1099-9809.6.2.196

Torres, L., Driscoll, M. W., \& Voell, M. (2012). Discrimination, acculturation, acculturative stress, and Latino psychological distress: A moderated meditational model. Cultural Diversity and Ethnic Minority Psychology, 18, 17-25. doi: 10.1037/a0026710

Tummala-Narra, P, Alegria, M., \& Chen, C. (2012). Perceived discrimination, acculturative stress, and depression among south Asians: Mixed findings. Asian American Journal of Psychology, 3, 3-16. doi: 10.1037/ a0024661

Vandiver, B. J., Cross, W. E., Fhagen-Smith, P. E., Worrell, F. C., Caldwell, L., Swim, J., \& Cokley, K. (2000). The Cross Racial Identity Scale. Unpublished scale created by a team of researchers from Penn State University and Southern Illinois University at Carbondale.

Vandiver, B. J., Cross, W. E., Worrell, F. C., Fhagen-Smith, P. E. (2002). Validating the Cross racial identity scale. Journal of Counseling Psychology, 49, 71-85. doi: 10.1037//0022-0167.49.1.71

Vandiver, B. J., Fhagen-Smith, P. E., Cokley, K. O., Cross, W. E., \& Worrell, F. C. (2001). Cross's nigrescence model: From theory to scale to theory. Journal of Multicultural Counseling and Development, 29, 174-200. doi: 10.1002/j.2161-1912.2001.tb00516.x

Wilcots, K. D. (2001). The relationship between racial identity, ethnic identity, and African American acculturation and their contribution to psychological well-being. Unpublished doctoral dissertation, University of North Texas, Denton.

Williams-Flournoy, D. F., \& Anderson, L. P. (1996). The acculturative stress scale: Preliminary findings. Handbook of Tests and Measurements for Black Populations, 2, 351-358. Hampton, VA: Cobb and Henry.

Wilson, J. W., \& Constantine, M. G. (1999). Racial identity attitudes, selfconcept, and perceived family cohesion in Black college students. Journal of Black Studies, 29, 354-366.

Worrell, F. C., Cross, W. E., Jr., \& Vandiver, B. J. (2000). The Cross Racial Identity Scale: Technical Manual. Unpublished manual.

Worrell, F. C., Cross, W. E., \& Vandiver, B. J. (2001). Nigrescence theory: Cur- 
rent status and challenges for the future. Journal of Multicultural Counseling \& Development, 29, 201-213.

Worrell, F. C., \& Watson, S. (2008). A confirmatory factor analysis of Cross Racial Identity Scale (CRIS) scores: Testing the expanded nigrescence model. Educational and Psychological Measurement, 68, 1041-1058. doi: $10.1177 / 0013164408318771$

Yip, T., Seaton, E. K., \& Sellers, R. M., (2006). African American racial identity across the lifespan content, and depressive symptoms. Child Development, 77, 1504-1517. doi: 10.1111/j.1467-8624.2006.00950. 